\title{
DINAMIKA INTERAKSI ANTARETNIK DALAM MEWUJUDKAN KESERASIAN SOSIAL DI WILAYAH PERBATASAN NEGARA INDONESIA - MALAYSIA
}

\author{
Agus Sikwan \\ Fakultas Ilmu Sosial dan Politik, Universitas Tanjungpura, Pontianak, 78124 \\ agussikwan@gmail.com
}

Diterima: 23 Juli 2017

Direview: 13 Sepetember 2017

Diterbitkan: 30 November 2017

Hak Cipta @ 2017 oleh Penulis (dkk) dan Jurna Sosial Humaniora (JSH)

*This work is licensed under the Creative

Commons Attribution International License (CC

BY 4.0).

http://creativecommons.org/licenses/by/4.0/

Open Access
Subject Areas: Sosiology

\begin{abstract}
The research reveals the dynamics of interaction between the three major ethnic groups (ethnic Dayak, Malay and Chinese) living in Entikong Subdistrict. These interactions are manifested in social relationships, ie relationships as relatives, as friends. Through qualitative analysis, the relationship is still strong in primordial loyalty among ethnic groups. It is characterized by a tendency to choose individuals from their own ethnic groups to serve as relatives. The results also show that there are two forms of ethnic group settlements in Entikong Subdistrict, namely: Mixed pattern, ie settlement area in which consists of various ethnic groups, in which there is more intensive inter-ethnic social contact that can encourage the realization of harmony social; Separate pattern, ie settlement area which consists of one ethnic group of the same kind, generally inhabited by Chinese ethnic groups. The change of settlement pattern indirectly caused by the expansion of subdistricts and population growth.
\end{abstract}

Keywords: Interaction; Social Harmony

\section{PENDAHULUAN/LATAR BELAKANG}

Bedasarkan data dari Kantor Kepolisian sektor (Polsek) Entikong Tahun 2015, menyebutkan bahwa sejak bulan Januari 2012 - Desember 2014 di Kecamatan Entikong telah terjadi sebanyak 12 kali pertikaian atau konflik di antara ketiga etnik besar (Melayu, Dayak dan Cina) baik secara individu maupun kelompok, yakni konflik antara etnik Melayu dan Dayak sebanyak 6 kali, Melayu dan Cina sebanyak 2 kali, Dayak dengan Cina sebanyak 4 kali. Adapun konflik yang terjadi menyangkut masalah penguasaan lahan, perebutan sumber mata pencaharian, akses lapangan pekerjaan, hutangpihutang, bisnis, pengiriman TKI/TKW ke luar negeri, dan lain-lainya. Hal ini belum lagi ditambah dengan konflik antara warga negara Indonesia dengan warga negara Malaysia di wilayah perbatasan yang menyangkut masalah tapal batas, dan ilegal loging yang sampai saat ini masih sering terjadi.

Meskipun pemerintah kecamatan telah bekerjasama dengan instansi terkait termasuk pihak kepolisian setempat telah melakukan berbagai sosialisasi kepada warga masyarakat di Kecamatan Entikong dalam upaya menciptakan suasana keharmonisan sosial dalam rangka mewujudkan integrasi bangsa di wilayah perbatasan, namun hasilnya masih sangat jauh dari yang diharapkan, yakni konflik dan pertikaian antaretnik masih saja terjadi. Kondisi ini mengakibatkan keresahan- 
keresahan dimasyarakat dalam kehidupan sosial mereka sehari-hari.

Dari hasil pengamatan di lapangan, maka dapat diketahui bahwa dalam kehidupan masyarakat di Kecamatan Entikong (wilayah perbatasan negara Indonesia - Malaysia) di dalamnya tidak ditemui adanya kelompok etnik yang menduduki posisi sebagai kelompok etnik dominan (dominant culture). Berdasarkan hasil pengamatan yang penulis lakukan di lapangan, maka dapat diketahui bahwa spesifikasi hubungan antaretnik di wilayah perbatasan negara Indonesia - Malaysia (di Kecamatan Entikong) disebabkan oleh faktor-faktor : pertama, ketiadaan kelompok etnik yang berperan sebagai "dominant culture group" (kelompok budaya yang dominan); kedua, adanya pengelompokan pemukiman etnik seperti kampung Melayu, Dayak, dan Cina; dan ketiga, adanya preferensi bidang okupasi etnik. Preferensi bidang okupasi tersebut meliputi bidang pekerjaan seperti orang Cina menguasai bidang bisnis dan perdagangan, orang Melayu mendominasi di birokrasi pemerintahan (pegawai negeri), sementara orang Dayak mendominasi pekerjaan di bidang pertanian dan perkebunan.

Demikian pula halnya dalam aspek durasi menetap, terdapat tiga pola permukiman orang Melayu yaitu permukiman membaur, setengah membaur, dan mengelompok (segregatif), orang Dayak yaitu dengan permukiman setengah membaur, sedangkan orang Cina dengan permukiman mengelompok. Menurut Alqadrie (1996 : 30) bahwa semakin tersegregasi pola permukiman suatu kelompok etnik, maka semakin kecil peluang terjadinya integrasi dengan etnik lainnya. Sebab keadaan yang demikian itu justru dapat memelihara jarak sosial di antara mereka. Namun pertumbuhan wilayah perbatasan negara Indonesia - Malaysia (di
Kecamatan Entikong) yang ditandai dengan berkembangnya bidang bisnis dan perdagangan antarnegara, meyebabkan terjadinya mobilitas penduduk ke kawasan tersebut. Ada pula perpindahan pemukim dari kawasan permukiman etnik ke kawasan permukiman yang membaur dan permanen sebagai wujud keberhasilan atau kemapanan ekonomi anggota-anggota kelompok etnik tertentu. Dengan demikian, secara tidak langsung terjadinya mobilitas individu kelompok etnik antarpermukiman akan mewarnai suatu wilayah permukiman dimana di dalamnya terdapat pemukim dengan durasi menetap yang lama dan yang relatif baru.

Ketiadaan budaya dominan serta adanya berbagai segregasi dalam kehidupan sebagaimana tersebut di atas, menunjukan bahwa hubungan antaretnik itu telah terkendala oleh "bentengbenteng" pemisah yang tercipta dalam kehidupan kompetitif di wilayah perbatasan. Benteng-benteng pemisah dalam hubungan antaretnik itu telah diperkuat oleh prasangka sosial, diskriminasi etnik, dan jarak sosial. Berdasarkan kenyataan tersebut, penelitian tentang dinamika interaksi sosial antaretnik dalam rangka perwujudan keserasian sosial antaretnik, khususnya ketiga etnik besar (etnik Melayu, Dayak dan Cina) di wilayah perbatasan negara Indonesia - Malaysia dilakukan dengan menempatkan unsur prasangka sosial, stereotipe, dan jarak sosial antaretnik sebagai determinan serta faktor pendidikan, pekerjaan, durasi menetap, dan toleransi beragama sebagai varian pembeda.

Berdasarkan latar belakang masalah penelitian yang telah dikemukakan, diperoleh gambaran bahwa dinamika interaksi antaretnik (etnik Melayu, Dayak dan Cina) di wilayah perbatasan yang sering menimbulkan ketidakharmonisan sosial 
antara lain disebabkan karena adanya prasangka sosial, stereotipe, dan jarak sosial di antara mereka. Selanjutnya identifikasi fokus penelitian ini dapat dirumuskan dalam bentuk pertanyaan penelitian (problem question), yakni sebagai berikut : Bagaimanakah upaya menciptakan suasana keserasian sosial dalam interaksi antaretnik pada masyarakat multikultural di wilayah perbatasan yang masing-masing memiliki prasangka sosial, stereotipe, dan jarak sosial antara etnik satu dengan yang lainnya.

\section{METODE PENELITIAN}

\section{A. Jenis Penelitian}

Jenis penelitian yang digunakan dalam penelitian ini adalah deskriptif analisis dengan menggunakan pendekatan kualitatif. Adapun yang dimaksud deskriptif analisis, yaitu suatu penelitian yang hasilnya menggambarkan objek penelitian yang berupa peristiwa atau gejala sosial secara apa adanya dengan melakukan analisis terhadapnya berdasarkan data yang diperoleh pada saat penelitian lapangan berlangsung.

Dalam penelitian ini, penulis menggunakan teoriteori yang relevan dengan masalah yang diteliti, dan telah disusun terlebih dahulu untuk memahami kenyataan sosial yang terjadi dimasyarakat pesisir. Di samping itu juga, dalam penelitian ini penulis akan membandingkan data atau kenyataan dengan teori-teori dan mencoba memahaminya menurut prosedur interpretasi.

\section{B. Teknik dan Alat Pengumpulan Data}

Adapun teknik pengumpulan data yang dipergunakan dalam penelitian ini adalah:

1. Teknik wawancara mendalam (In-depth Interview), kegiatan ini dimaksudkan untuk mengadakan percakapan dengan subjek penelitian (informan) dengan maksud (Lincoln dan Guba, 1985: 266) "untuk mengkonstruksi mengenai aktivitas" yang dilakukan masyarakat dari tiga kelompok etnik besar (etnik Melayu, Dayak dan Cina) di wilayah perbatasan yang bersangkutan dengan dinamika interaksi sosial di antara mereka, faktor-faktor yang menyebabkan terjadinya konflik dalam interaksi sosial antaretnik, serta memproyeksikan model interaksi sosial antaretnik yang dapat menciptakan suasana keharmonisan sosial, dan sebagainya. Adapun alat pengumpulan data yang dipergunakan dalam teknik wawancara mendalam ini adalah pedoman wawancara.

2. Teknik observasi non partisipatif (Pengamatan tidak berperan serta), kegiatan ini peneliti lakukan dengan tidak berpartisipasi secara langsung dalam setiap interaksi sosial yang dilakukan tiga etnik besar (Melayu, Dayak dan Cina) baik di dalam maupun di luar rumahnya. Di lokasi penelitian peneliti mengadakan penyempurnaan catatan lapangan, melakukan klarifikasi data lapangan, menyusun transkripsi rekaman wawancara, melakukan observasi dan wawancara yang berkaitan dengan data yang relevan dan membina hubungan baik dengan ketiga etnik besar tersebut. Melalui observasi non partisipatif (pengamatan tidak berperan serta) ini, peneliti mencatat dan merekam semua kejadian sebagaimana terjadi dalam dinamika yang sebenarnya. Pengamatan juga dilakukan terhadap sikap, perilaku masing etnik, dan interaksi sosial di antara ketiga etnik besar tersebut di lingkungan sosialnya. Adapun alat pengumpulan data yang dipergunakan dalam teknik observasi non partisipatif ini adalah pedoman observasi.

3. Teknik studi dokumenter, kegiatan ini peneliti lakukan untuk menggali data sekunder yang 
diperlukan untuk menunjang penelitian ini. Dokumen pada umumnya diperoleh dari dokumen milik pemerintah daerah setempat, hasil- penelitian terdahulu, jurnal ilmiah, karya tulis (makalah), artikel ilmiah, dan dokumen dari instansi lainnya yang berhubungan dengan masalah penelitian. Adapun alat pengumpulan data yang penulis pergunakan dalam teknik studi dokumenter ini adalah foto copy.

\section{Subjek Penelitian}

Adapun yang dijadikan subjek penelitian adalah masyarakat Melayu, Dayak dan Cina yang bermukim di wilayah perbatasan negara Indonesia - Malaysia (Kecamatan Entikong Kabupaten Sanggau) yang selanjutnya disebut informan. Penentuan informan dalam penelitian ini dilakukan secara purposif sampling, seperti yang diungkapkan oleh Sugiyono (1998: 68), yaitu teknik penentuan sampel yang ditujukan kepada informan yang benar-benar mengetahui permasalahan sesuai dengan tujuan penelitian.

Di samping itu, peneliti juga menggunakan informan pangkal yang terdiri dari tokoh formal seperti camat, kepala desa, kepala dusun, Ketua RW/RT dan para guru, dan tokoh informal (tokoh masyarakat, tokoh agama, pemuka adat) dari ketiga etnik besar (Melayu, Dayak dan Cina) yang tinggal di wilayah perbatasan. Menurut Koentjaraningrat (1991: 164), informan pangkal adalah mereka yang mempunyai pengetahuan luas mengenai berbagai sektor dalam masyarakat serta mempunyai kemampuan untuk mengintroduksikan kepada peneliti untuk menghubungi informan lain yang merupakan ahli tentang sektor-sektor masyarakat atau unsur-unsur yang ingin peneliti ketahui.

\section{Teknik Analisis Data}

Pada umumnya analisis merupakan upaya mencari dan menata secara sitematik catatan hasil observasi, wawancara mendalam, dokumentasi dan kajian pustaka untuk meningkatkan pemahaman terhadap masalah yang diteliti. Adapun pemahaman tersebut sebagai analisis yang dilanjutkan dengan mencari makna.

Sehubungan dengan hal tersebut, maka analisis data dalam penelitian ini adalah menggunakan analisis deskriptif. Menurut Martodirdjo (1991: 85) analisis deskriptif adalah usaha untuk menyederhanakan dan sekaligus menjelaskan bagian dari keseluruhan langkah-langkah klasifikasi dan kategorisasi sehingga dapat tersusun suatu rangkaian deskripsi yang sistematis sehingga memperoleh suatu kesimpulan.

Proses kategorisasi dan klasifikasi data dilakukan secara bertahap atas informasi dari para informan. Untuk lebih jelasnya mengenai langkahlangkah analisis data dalam penelitian ini, yakni antara lain: langkah pertama, data yang diperoleh dari hasil pengumpulan data lapangan selanjutnya dilakukan pemisahan-pemisahan atau pengkategorisasian, pengklasifikasian sehingga memudahkan peneliti untuk melakukan analisis (proses reduksi data), selanjutnya langkah kedua, dilakukan penafsiran data dan pemeriksaan data atau verifikasi.

Reduksi data bermakna memilah-milah data yang dianggap relevan dengan masalah penelitian, dan kemudian menggolongkan serta mengorganisasikan data itu sesuai dengan jenisnya. Dalam melakukan pekerjaan reduksi data ini, kegiatan yang dilakukan adalah membuat rangkuman inti, proses dan pernyataan yang perlu dijaga supaya tetap berada di dalamnya dari data yang diperoleh 
yaitu dengan menyusunnya ke dalam bentuk satuansatuan dari berbagai sumber seperti hasil wawancara mendalam dan observasi di lapangan sehinggga dapat diidentifikasi.

\section{PERWUJUDAN INTERAKSI ANTAR KELOMPOK ETNIK DALAM KEHIDUPAN SOSIAL KEMASYARAKATAN DI KECAMATAN ENTIKONG}

\section{A. Gambaran Struktur Interaksi Antar}

\section{Kelompok Etnik}

Pada umunya keberadaan budaya dominan setidaknya akan mempermudah terwujudnya keserasian hidup di antara berbaga kelompok, oleh karena setiap individu dalam perilakunya cenderung mengacu pada norma-norma, adat istiadat dan nilainilai yang sama, menggunakan simbol-simbol yang yang sama terutama bahasa. Setiap orang akan mengacu pada nilai-nilai yang sama, maka unsurunsur prasangka, stereotipe antar individu dan kelompok etnik sukar untuk muncul pada diri setiap individu. Pada gilirannya jarak sosial di antara mereka pun tidak akan terbuka lebar.

Keadaannya agak berbeda dalam masyarakat yang tidak mengenal adanya budaya dominan, seperti halnya di Kecamatan Entikong. Dalam keadaan seperti ini masing-masing kelompok etnik cenderung untuk mempertahankan identitas etniknya. Begitu juga dalam berbagai kegiatan sosial dan ekonomi cenderung dikembangkan oleh masing-masing kelompok etnik. Ketiadaan budaya dominan tersebut seakan-akan membuka peluang menguatnya kesetiaan primordial tiap kelompok etnik.

Dalam kerangka hubungan antar kelompok etnik yang lebih luas, akan ditemui bahwa di antara kelompok etnik mempunyai stereotipe dan prasangka terhadap kelompok etnik lain. Prasangka bukanlah sesuatu yang melekat (inheren) di dalam diri manusia, melainkan sesuatu yang berkaitan dengan intensitas interaksi sosial. Prasangka dapat berwujud rasa permusuhan terhadap seseorang dari kelompok lain, sedangkan stereotipe merupakan atribut yang berfungsi sebagai suatu pembeda (label of difference) yang diarahkan kepada individu dari kelompok tertentu.

Faktor prasangka sosial dan stereotipe tidak selalu harus memutus hubungan kerjasama dan hubungan sosial lainnya di antara individu satuan etnik yang berbeda. Hal tersebut terutama jika interaksi di antara mereka tertata dengan baik dan intensif melalui arena-arena sosial di mana terdapat kegiatankegiatan sosial yang dapat menjembatani sikap-sikap yang kurang bersahabat di antara individu satuan etnik.

Gambaran struktur interaksi antar kelompok etnik di Kecamatan Entikong yang menjadi perhatian adalah kombinasi spesifik hubungan atau interaksi antar kelompok etnik Dayak, Melayu, dan Cina dalam situasi sosial. Sifat hubungan yang diamati adalah gambaran hubungan yang diklasifikasikan ke dalam tiga sifat hubungan. Ketiga sifat hubungan tersebut adalah : (1) sebagai keluarga atau kerabat; (2) sebagai sahabat; dan (3) sebagai teman atau kenalan. Adapun sifat hubungan tersebut diperkirakan akan menghasilkan corak interaksi antar etnik yang ditunjukkan dalam gambaran struktur hubungan antar etnik. Selain itu, dengan menggunakan ketiga sifat hubungan tersebut, akan dapat diperoleh gambaran unsur-unsur parasangka sosial, stereotipe, dan jarak sosial di antara kelompok-kelompok etnik tersebut.

Adapun tolok ukur yang digunakan untuk melihat bagaimana gambaran struktur interaksi antar etnik berdasarkan ketiga sifat hubungan sebagaimana 
tersebut di atas, adalah kecenderungan individu satuan kelompok etnik sebagai kelompok etnik yang disenangi, baik dari kelompok etniknya sendiri maupun individu satuan etnik dari kelompok etnik lain.

Dengan cara seperti itu akan tampak dari tiga kelompok etnik besar (etnik Dayak, Melayu, dan Cina) di Kecamatan Entikong yang menjadi unit analisis dalam penelitian ini, akan diketahui kelompok etnik mana yang secara relatif sangat disenangi oleh kelompok-kelompok etnik tersebut. Berdasarkan pada keadaan tersebut dapat dinyatakan bahwa suatu kelompok etnik dapat disebut sebagai kelompok etnik favorit bagi semua kelompok etnik. Sebaliknya juga akan nampak pula kelompok etnik mana yang tidak disenangi oleh kelompok-kelompok etnik lain.

Kecenderungan seperti ini merupakan sesuatu yang umum terjadi di dalam kehidupan masyarakat. Faktor yang menjadi pertimbangan adalah bahwa dengan memilih individu dari kelompok etnik sendiri secara relatif bagi individu akan lebih mudah beradaptasi oleh karena adanya berbagai kesamaan seperti adat istiadat, nilai-nilai, keyakinan, dan unsurunsur budaya lain. Hal ini sejalan dengan pendapat Levine \& Campbell (1972 : 40), yang mengatakan antara lain: "justru manakala ada kesamaan berbagai faktor seperti kebiasaan, nilai-nilai, dan keyakinan tersebut pada suatu kelompok, menjadi pertimbangan kelompok akan saling memilih atau menyukai”. Kecenderungan memilih pada kelompok etnik sebagaimana tersebut di atas memperlihatkan bahwa masih demikian kuatnya kesetiaan primordial di kalangan kelompok-kelompok etnik dalam rangka menjalin hubungan kekerabatan.

Kecenderungan untuk memilih individu dari kelompok etnik sendiri didasarkan atas berbagai pertimbangan tertentu. Pada umumnya menempatkan alasan atau argumentasi antara lain adalah jika perkawinan dilakukan sesama etnik, maka "kemurnian" kelompok etniknya akan terjaga secara berkesinambungan. Cara pandang ini tampaknya agak konservatif serta tetap mengukuhkan salah satu sikap etnosentrisme berupa penguatan kesetiaan primordial yang terwujud di dalam perilaku memilih sesama etnik untuk dijadikan anggota keluarga atau kerabat. Atribut yang dijadikan pegangan adalah kesamaan etnik dan kesamaan agama. Cara pandang seperti ini umumnya masih melekat pada kelompok generasi tua, di mana dalam sebagian besar daur hidupnya dilalui masih teguh mempraktekkan nilainilai buadayanya.

Upaya untuk menjaga "kemurnian" kelompok etnik ini tidak selamanya dapat terwujud, oleh karena cara pandang generasi muda yang berbeda dibandingkan dengan generasi tua atau orang tua mereka. Jika kelompok generasi tua atau orang tua menggunakan atribut kesamaan etnik dan kesamaan agama sebagai tolok ukur, maka pada kelompok generasi muda adalah hanya pada atribut kesamaan agama tanpa mempersoalkan latar belakang etniknya.

Meskipun tampaknya ada perbedaan cara pandang di antara generasi tua dan generasi muda, akan tetapi dalam prakteknya dalam kelompok-kelompok etnik tertentu terdapat fleksibilitas yaitu menyerahkan keputusan kepada generasi muda atau anak-anak yang akan menentukan pilihan mereka sendiri meskipun secara pribadi orang tua masih teguh dengan pendirian mereka.

Hal ini sejalan dengan pendapat dari Tokoh masyarakat di Kecamatan Entikong bernama Bapak IS (60 th) yang mengungkapkan bahwa umumnya para orang tua yang tinggal di Kecamatan Nanga Pinoh ini cenderung untuk memilih menantu atau 
kerabat orang yang berasal dari kelompok etniknya sendiri. Adapun hal ini selain disebabkan karena adanya persamaan budaya dan adat istiadat, mudah beradaptasi, juga ikatan tali silaturahmi sesama kelompok etnik semakin erat.

Demikian pula pernyataan yang diungkapkan oleh seorang Tokoh agama bernama Bapak MD (62 th), yakni para orangtua di Kecamatan Entikong yang agamanya fanatik, baik ia beragama Islam, Khatolik, Kristen maupun agama yang lainnya, sangat menganjurkan kepada anak-anaknya untuk memilih teman hidup adalah orang yang memeluk agama yang sama dengan agama yang dianut oleh keluarganya. Karena hal ini selain menyangkut kebahagiaan hidup anaknya di dunia juga kebahagian hidup di akhirat nanti.

Sungguhpun dalam hal pemilihan untuk hubungan sebagai kerabat di mana masing-masing kelompok etnik cenderung memilih individu dari kalangan etnik sendiri, nampaknya faktor pergaulan antar etnik di dalam suatu wilayah permukiman yang demikian heterogen dapat mempengaruhi sikap individu dalam memilih pasangan. Terutama bagi mereka yang berumur kurang dari 40 tahun dapat digolongkan sebagai kelompok yang mempunyai kerabat yang berasal dari luar kelompok etniknya. Kondisi dengan iklim pergaulan antar etnik yang heterogen dalam suatu wilayah permukiman dapat menimbulkan kesan pribadi individu satuan etnik terhadap individu satuan etnik lain. Tampaknya faktor permukiman dan durasi menetap yang dapat menimbulkan kesan pribadi serta daya tarik personal, pada gilirannya akan dapat menciptakan atau melahirkan iklim hubungan yang serasi. Iklim yang demikian memungkinkan untuk terjadinya perkawinan antar kelompok etnik yang berbeda, Cohen (1974) menyebut hal seperti itu sebagai amalgamasi.
Berdasarkan hasil observasi yang penulis lakukan di lapangan, maka tampaknya perkawinan antar etnik di Kecamatan Entikong tidak akan menjadi ganjalan, karena didukung oleh faktor oleh faktor permukiman dan durasi waktu bermukim.

Kesan umum yang muncul terhadap kelompok etnik Cina di kalangan kelompok-kelompok etnik lain (seperti etnik Dayak, Melayu, dan Jawa) menempatkan mereka sebagai kelompok etnik yang kurang disenangi oleh kelompok-kelompok etnik lain di Kecamatan Entikong, yakni etnik Cina umumnya kurang adaptif. Hal tersebut disebabkan karena umumnya etnik Cina menggeluti aktifitas usaha di bidang ekonomi. Pekerjaan yang menyita sebagian besar waktu kehidupan sehari-hari, menyebabkan munculnya kesan bahwa mereka memiliki sikap sombong atau menjauhkan diri dari kalangan kelompok etnik pribumi. Keadaan seperti ini menunjukkan bahwa orang Cina kurang dekat dengan etnik-etnik pribumi serta terkesan seolaholah tertutup. Ada kesan bahwa orang Cina hanya mau berinteraksi dengan orang di luar kelompoknya manakala ia mempunyai "keperluan", sedangkan jika tidak ada keperluan mereka cenderung untuk tidak melakukannya. Dari kondisi seperti ini ada pepatah yang berkembang di kalangan etnik pribumi terhadap etnik Cina di Kecamatan Entikong, yaitu: "ada perlu ada kawan, tidak ada perlu tidak ada kawan". Pepatah ini seakan-akan mengandung makna bahwa etnik Cina hanya membina intaraksi sosial di kalangan kelompok etniknya saja.

Ditinjau dari aspek permukiman dan kondisi sosial ekonomi, tampak sekelompok etnik Cina yang bertempat tinggal di lingkungan etnik-etnik pribumi sementara status sosial ekonomi mereka tergolong menengah ke bawah, maka tingkat adaptasinya cukup baik. Sikap adaptasi tersebut terwujud berupa 
kesediaan mereka bergaul dengan masyarakat sekitar tempat tinggal mereka yang tampak antara lain ikut serta dalam aktifitas sosial masyarakat seperti gotong royong, aktifitas olah raga seperti bola voli, bulu tangkis, tenis meja, serta kesediaan mereka dalam memberikan sumbangan materi dalam berbagai kegiatan kemasyarakatan yang dilaksanakan di lingkungannya antara lain seperti acara-acara hiburan perayaan hari ulang tahun kemerdekaan. Jadi keterlibatan mereka dalam komunitas masyarakat tersebut tidak hanya kesediaan memberikan sumbangan berupa materi, tetapi juga kesediaan mereka secara fisik untuk bergaul dalam interaksi sosial sehari-hari.

Meskipun secara umum ada kesan bahwa etnik Cina cenderung menjaga jarak, menutup diri, bersikap sombong, akan tetapi kondisi itu sudah barang tentu tidak dapat digeneralisasikan. Dalam kasus-kasus tertentu terutama manakala telah terjadi perkawinan antara individu etnik Cina dengan etnik pribumi seperti di antaranya perkawinan etnik Cina dengan etnik Dayak, Melayu, atau Jawa, atau keadaan di mana beberapa etnik Cina bermukim di sekitar kelompok etnik pribumi di mana mereka mau melibatkan diri berupa partisipasi secara fisik maupun materi dalam berbagai kegiatan kemasyarakatan, keadaannya justru tidak demikian. Dalam keadaan seperti itu umumnya mereka menunjukkan sikap yang agak berbeda dalam arti tidak terlalu menunjukkan "sikap-sikap keCinaannya" secara mencolok. Malah seolah-olah kenetralan itu tampak dari sikap untuk mengedepankan pertimbangan bahwa mereka merupakan bagian dari lingkungan sosial masyarakat di mana mereka berada.

Tampaknya, meskipun pada umumnya kelompokkelompok etnik pribumi memiliki kesan bahwa etnik
Cina kurang dekat dengan etnik-etnik pribumi, akan tetapi hal tersebut belum merupakan suatu kesimpulan final. Dalam kasus-kasus tertentu sebagaimana yang telah dijelaskan bahwa jika telah terjadi perkawinan antara etnik Cina dengan etnik pribumi, atau jika etnik Cina bertempat tinggal di wilayah yang relatif heterogen di mana sebagian besar adalah kelompok etnik pribumi, maka kecenderungannya adalah bahwa etnik Cina menunjukkan sikap adaptif terhadap lingkungan sosialnya, karena mereka umumnya mencari "aman" dalam hidupnya.

Di sisi lain bahwa munculnya kesan bahwa etnik Cina suka menjaga jarak, tertutup, terkesan sombong, adalah dikarenakan pola permukiman etnik Cina sebagian besar hidup mengelompok. Keadaan seperti ini justru akan mempertegas "batas fisik" serta juga "batas sosial" antara etnin Cina dengan etnik-etnik pribumi. Implikasinya adalah di antara etnik Cina dan kelompok etnik pribumi akan merasa "jauh" satu sama lain serta kurang melihat keberadaan masingmasing kelompok sebagai satu kesatuan masyarakat. Kecenderungan hidup mengelompok etnik Cina menurut salah seorang informan dari warga etnik Cina bernama A Chai (40 th), adalah karena adanya perasaan "canggung" di kalangan orang Cina jika bergul dengan etnik pribumi. Itu dikarenakan kurangnya kebiasaan untuk bergaul pada kelompok etnik Cina.

\section{B. Bahasa Sebagai Media Komunikasi Antar \\ Etnik}

Suatu fenomena yang dapat diamati dalam kehidupan sosial kelompok etnik di Kecamatan Entikong adalah dalam hal penggunaan bahasa sebagai alat komunikasi. Bahasa sebagai bagian atau salah satu unsur kebudayaan masih digunakan dalam praktek kehidupan sosial kelompok etnik. Bahasa ibu 
kerap terdengar digunakan terutama oleh individu satuan etnik manakala terjadi interaksi tatap muka dengan sesama etniknya, terutama di lingkungan masyarakat di mana terdapat pengelompokkan perumahan etnik dalam satu wilayah yang sama.

Penggunaan bahasa ibu tersebut terlebih-lebih dgunakan di dalam acara-acara pertemuan di dalam kelompok tiap etnik. Acara-acara yang dilaksanakan di dalam perkumpulan-perkumpulan sosial berupa perkumpulan kedaerahan antara lain seperti: Majelis Adat Budaya Dayak (MABD), MABM (Majelis Adat Budaya Melayu), Majelis Adat Budaya Tionghoa (MABT), Kerukunan Masyarakat Jawa (KMJ), Ikatan Kekerabatan Masyarakat Minang (IKAMAMI), Kerukunan Keluarga Banjar (KKB) dan lain-lain. Dalam perkumpulan tersebut, maka proses interaksi yang terjadi di dalamnya umumnya didominasi oleh penggunaan bahasa daerah sebagai media komunikasi. Seperti dalam MABD digunakan bahasa Dayak sebagai bahasa pengantar, dalam MABD akan digunakan bahasa Melayu, dan sebagainya. Hal yang demikian, sebagaimana yang dinyatakan Parsons (1981) bahwa bahasa mempunyai kedudukan sebagai aspek yang paling menonjol dari suatu identitas budaya.

Pengukuhan simbol-simbol kelompok etnik antara lain berupa penggunaan bahasa daerah melalui wadah sosial, pada kelompok etnik tertentu disadari atau tidak, juga digunakan dalam situasi interaksi atau kontek sosial yang lain. Kontek sosial tersebut sepeti di pasar, rumah sakit, di pusat perbelanjaan atau di pertokoan. Meskipun kebiasaan seperti ini tidak dapat digeneralisasikan pada semua kelompok etnik, akan tetapi pada kelompok-kelompok etnik tertentu perilaku menggunakan bahasa daerah seperti ini dapat diamati. Dalam kaitan ini, De Vos (1982:
30) menyatakan bahwa bahasa membentuk ciri tunggal dari suatu bentuk pemisahan identitas etnik.

Di antara beberapa kontek sosial seperti yang telah disinggung, maka yang agak mencolok penggunaan bahasa daerah adalah di pasar. Pasar sebagai tempat di mana individu berinteraksi dengan berbagai latar belakang yang berbeda termasuk latar belakang kelompok etnik, merupakan tempat di mana perbedaan-perbedaan sosial saling bertemu. Karakteristik pasar yang ada di kota Entikong antara lain adalah : (1) Pasar yang relatif sebagian besar pedagangnya didominasi oleh satu kelompok etnik tertentu (etnik Cina) oleh karena pasar tersebut berlokasi di wilayah permukiman homogen yang penduduknya merupakan kelompok etnik mayoritas, misalnya Pasar Sentral atau Pusat Pasar; (2) Kemudian pasar yang tidak berlokasi di wilayah di mana terdapat suatu kelompok etnik tertentu dalam jumlah mayoritas. Pasar yang berada di lokasi seperti ini di dalamnya ditemui proporsi pedagang dari kelompok etnik yang relatif heterogen, meskipun jumlahnya tidak persis sama. Tipe pasar seperti ini merupakan tipe sebagian besar sebagian besar yang ada di kota Entikong. Beberapa pasar yang termasuk ke dalam lokasi yang relatif heterogen antara lain Pasar tradisional, Pasar pagi, Pasar rakyat, dan lainlain.

Dari dua karakteristik pasar tersebut, maka yang agak kontras suasana di dalammnya dalam hal penggunaan bahasa adalah di dalam pasar tipe pertama. Misalnya saja pasar yang terutama didominasi oleh etnik Cina seperti Pasar Sentral atau Pusat Pasar yang terutama didominasi oleh etnik Cina tampak intensitas penggunaan bahasa Cina cukup tinggi. Selain di dalam lingkungan pasar seperti yang telah disinggung, melainkan juga di tempat-tempat umum seperti pusat perbelanjaan, 
pertokoan, maka penggunaan bahasa Cina dalam interaksi antara sesama individu satuan etnik Cina kerap kali terdengar. Tampaknya bahasa merupakan sarana terpenting yang mendekatkan atau menghubungkan orang Cina dengan sesamanya. Bahasa seolah-olah merupakan komponen perekat jaringan interaksi di kalangan etnik Cina. Pada gilirannya kebiasaan untuk mengutamakan penggunaan bahasa ibu, kerap kali juga digunakan di seberang tempat walaupun proses interaksi itu terjadi di tengah-tengah individu dari satuan kelompok etnik lain yang sama sekali tidak memahami makna pembicaraan.

Interaksi dapat berjalan dengan baik melalui suatu media. Dalam situasi itu bahasa dapat dikatakan sebagai "shared values" yang esensial dalam mendukung kelancaran interaksi (Berger dan Luckman, 1990: 50). Manakala media bahasa tidak dapat menghasilkan pemahaman atau pengertian bersama, maka justru sebaliknya dapat menimbulkan kesalahpahaman antar kelompok etnik.

Bagi individu dari kelompok etnik lain, maka kemampuan menggunakan bahasa Cina merupakan suatu keberuntungan, selain dapat berkomunikasi maka ia juga akan mendapat respon yang lebih akrab dan agak terbuka. Hal yang demikian oleh karena bagi orang Cina bahasa merupakan faktor sangat penting dalam membina relasi sosial yang baik. Dengan kemampuan berkomunikasi dalam bahasa Cina, akan menjadi ukuran bagi individu etnik Cina untuk bersikap terhadap orang lain. Ukuran dimaksud antara lain apakah bisa mempercayai seseorang atau tidak khususnya dalam aktivitas bisnis. Itu pula agaknya mengapa di dalam perusahaan yang dimiliki etnik Cina, maka mereka cenderung menempatkan etnik Cina pada tempat yang lebih strategis dibanding terhadap individu dari kalangan etnik pribumi seperti misalnya menduduki jabatan bagian kepegawaian dan keuangan.

Berdasarkan hasil observasi dan wawancara yang penulis lakukan dengan beberapa informan dari masing-masing ketiga kelompok etnik besar (etnik Dayak, etnik Melayu, dan etnik Cina) di Kecamatan Entikong, maka dapat diketahui bahwa kecenderungan penggunaan bahasa dalam berkomunikasi di antara sesama etniknya di tempattempat umum adalah bahasa Indonesia. Hanya saja pada kelompok etnik Cina yang menampakkan kecenderungan menggunakan bahasa daerah sendiri yang lebih besar daripada menggunakan bahsa Indonesia dengan sesama kelompok etniknya manakala mereka berada di berbagai tempat umum.

Hasil observasi yang penulis lakukan di lapangan juga menunjukkan bahwa di dalam lembaga pendidikan, khususnya sekolah-sekolah swasta seringkali ditemui perilaku menggunakan bahasa Cina di kalangan murid-murid etnik Cina dalam berinteraksi di antara sesama mereka. Di kota kecamatan (Entikong) terdapat beberapa lembaga pendidikan negeri dan swasta mulai dari tingkat SD sampai tingkat Diploma. Di dalam lembaga pendidikan sekolah yang berstatus negeri, populasi siswa dari kalangan etnik Cina dapat dikatakan relatif kecil dibandingkan dengan siswa dari kelompok etnik lain.

Populasi terbesar siswa etnik Cina umumnya berada di sekolah-sekolah swasta terutama lembaga pendidikan yang dikelola oleh Yayasan yang dikelola oleh kelompok etnik Cina. Di luar lembaga tersebut, sebagian bisa di dalam lembaga pendidikan yang disebut sebagai "sekolah pembauran". Di dalam tipe sekolah seperti ini ditemui di dalamnya siswa dengan latar belakang etnik yang beragam seperti Dayak, 
Melayu, Cina, Jawa, Padang, dan beberapa etnik lainnya.

Meskipun penyelenggaraan sistem pendidikan sekolah pembauran ditujukan untuk membina kesadaran di antara siswa berupa kekompakkan dari latar belakang etnik yang berbeda, namun bukan berarti di dalam perjalanannya tidak ditemui hambatan. Studi yang dilakukan Lubis dan Dharmansyah (1989) menyimpulkan bahwa di kalangan siswa-siswa masih ditemukan adanya kecenderungan untuk mengelompok terutama pada siswa etnik Cina. Mereka masih senang menggunakan bahasa Cina di lingkungan sekolah sebagai bahasa pengantar dalam berinteraksi dengan sesama mereka, meskipun hasil studi tersebut tidak tergolong sebagai kajian terbaru, namun setidaknya masih relevan untuk mendukung fenomena yang ditemukan dalam penelitian ini. Kecenderungan penggunaan bahasa daerah sendiri di dalam situasi tempat-tempat umum tersebut akan menyebabkan tetap adanya kesan yang keliru atau kurang baik pada individu lain khususnya yang kurang memahami makna-makna pembicaraan dalam bahasa daerah tertentu. Kesan kurang baik itu dapat membentuk prasangka buruk yang pada gilirannya menimbulkan sikap ingin saling menjauhi. Dalam kasus kelompok etnik Cina yang cenderung menggunakan bahasa daerahnya, maka kesan keliru serta prasangka kurang baik akan tetap melekat pada diri individu satuan etnik lain terhadap etnik Cina. Kondisi seperti ini memperlihatkan adanya "rintangan interaksi" oleh karena tidak adanya pemahaman bersama di antara individu.

Kebiasaan penggunaan bahasa daerah yang demikian besar kemungkinan sangat dipengaruhi oleh pengalaman, terutama proses sosialisasi yang dialami sejak dalam kehidupan keluarga di rumah.
Menguatnya kebiasaan untuk menggunakan bahasa daerah sendiri merupakan produk dari kebiasaan yang dijalani di rumah. Sehinggga tampaknya ada kaitan antara pengalaman hidup di rumah dengan perilaku sosial dalam lingkungan yang lebih luas.

Berdasarkan hasil observasi dan wawancara yang penulis lakukan dengan informan dari kelima kelompok etnik besar (etnik Dayak, Melayu, Cina, Jawa, dan Padang) di Kecamatan Entikong, maka dapat diketahui bahwa dalam lingkup penggunaan bahasa sebagai alat komunikasi yang digunakan sehari-hari di rumah, maka terdapat variasi penggunaan bahasa sebagai alat komunikasi di rumah, yakni menurut para informan dari kelompok etnik pribumi seperti etnik Dayak, Melayu, Jawa, dan Padang mengungkapkan bahwa sebagian besar ( $>50$ \%) menyatakan menggunakan bahasa Indonesia dalam berinteraksi di rumah. Sedangkan menurut pengakuan informan dari kelompok etnik Cina, bahwa kelompok etnik Cina justru kebalikannya, yaitu sebagian besar ( > $60 \%$ ) yang menyatakan menggunakan bahasa daerah sendiri (bahasa Cina) dalam berinteraksi di rumah. Dengan demikian tampaknya proses sosialisasi di rumah membentuk kesadaran dan kebiasaan individu berperilaku termasuk kebiasaan menggunakan bahasa daerah dalam kehidupan sosial.

Menurut penuturan Camat Entikong (informan kunci) bahwa sebenarnya pemerintah telah mensosialisasikan kepada seluruh warga masyarakat di Kecamatan Entikong untuk mempergunakan bahasa Indonesia yang baik dan benar. Adapun sosialisasi ini selain diberikan di sekolah-sekolah, instansi-instasi, dan tempat-tempat umum yang sering dikunjungi orang, dengan cara memasang spanduk, stiker, pamflet dan lain-lain, namun masih 
saja terlihat warga masyarakat yang masih menggunakan bahasa daerahnya masing-masing.

Sehubungan dengan hal tersebut, maka dengan menguatnya kecenderungan warga masyarakat mempergunakan bahasa daerah akan menyebabkan bahasa Indonesia kehilangan nilai esensinya. Dalam kontek interaksi sosial antar etnik, bahwa penggunaan bahasa mempunyai nilai tersirat berupa kejujuran dan keterbukaan (Sutanto, 1996 : 40). Dalam kaitan ini, seseorang yang menggunakan bahasa sebagai alat komunikasi seharusnya memenuhi kriteria bahwa ia menerapkan kejujuran dan keterbukaan dalam berbicara, bahwa bahasa harus dipahami dalam suatu makna yang sama oleh individu yang berada dalam situasi di mana bahasa itu digunakan. Manakala bahasa justru menimbulkan perbedaan makna, maka dalam keadaan seperti ini justru nilai kejujuran dan keterbukaan dalam berkomunikasi tidak hadir dalam situasi itu.

Dengan demikian, kecenderungan menggunakan bahasa daerah di dalam arena interaksi sosial di kalangan individu satuan etnik-etnik di Kecamatan Entikong secara tidak langsung akan menimbukan “jurang pemisah", berupa jarak sosial atau alpanya perasaan intim antara satu sama lain. Kealpaan perasaan intim tersebut karena terhalangi oleh adanya kesan keliru atau kurang baik sebagai akibat kurangnya pemahaman terhadap makna pembicaraan yang dilakukan dalam bahasa daerah. Keadaan seperti ini pada gilirannya akan menjadi faktor yang dapat mempersulit untuk terwujudnya keserasian sosial di antara berbagai kelompok etnik tersebut.

\section{Wujud Keserasian Sosial Antar Etnik Dalam}

\section{Aktifitas Sosial}

Di dalam masing-masing wilayah desa yang diteliti dapat dikemukakan variasi kelompokkelompok etnik yang ada di dalamnya. Kelompok- kelompok etnik yang terdapat pada masing-masing desa di Kecamatan Entikong antara lain sebagai berikut :

1). Desa Entikong, Desa Semangat, dan Desa Nekan ditemui kelompok etnik besar antara lain: etnik Dayak, etnik Melayu, etnik Cina, serta terdapat pula kelompok etnik kecil lainnya seperti etnik Jawa, etnik Padang, etnik Bugis, etnik Sunda, etnik Batak, dan etnik Banjar.

2). Desa Pala Pasong dan Desa Suruh Tembawang ditemui juga ketiga kelompok etnik besar, yaitu enik Melayu, etnik Dayak, etnik Cina, dan ditemui juga kelompok etnik kecil lannya yaitu etnik Jawa, etnik Padang, etnik Bugis, etnik Banjar, etnik Sunda, etnik Palembang, etnik Ambon, dan etnik Batak.

Secara umum dapat dinyatakan bahwa iklim keserasian sosial antar etnik di wilayah penelitian tergolong ke dalam katagori baik jika menggunakan tolok ukur antara lain tidak pernahnya terjadi konflik yang sifatnya terbuka, meskipun potensi untuk terjadinya konflik tetap ada. Keserasian itu secara esensial dapat diamati dari keadaan di mana telah terbinanya suasana hidup saling pengertian di antara berbagai kelompok etnik serta adanya kepedulian sosial antar etnik. Kondisi seperti itu memperlihatkan adanya ikatan berupa jalinan hubungan rasa persaudaraan, persamaan, kasih sayang, gotong royong sehingga seolah-olah merupakan satu kesatuan organisme (Sanusi, 1987: 12). Wujud dari suasana yang demikian antara lain berjalannya kebiasaan di mana setiap kelompok etnik melibatkan diri dalam hal-hal seperti memberikan bantuan baik tenaga maupun materi. Bantuan yang diberikan dalam bentuk materi antara lain seperti memberikan sumbangan berupa uang jika terjadi musibah seperti 
kematian, sakit serta berusaha untuk menghadiri peristiwa itu.

Selain itu, juga ada kebiasaan saling memberikan ucapan selamat dalam setiap hari besar yang dirayakan oleh masing-masing kelompok etnik seperti Hari Raya Idul Fitri bagi yang beragama Islam, Natal dan Tahun Baru bagi yang beragama Kristen dan Khatolik, Hari Raya Waisak bagi yang menganut agama Budha, dan Hari Raya Imlek bagi yang menganut agama/kepercayaan Kong $\mathrm{Hu} \mathrm{Cu}$. Hal lain yang merupakan suatu bentuk partisipasi individu satuan etnik dalam kegiatan sosial kemasyarakatan antara lain seperti kegiatan gotong royong bersama membersihkan tempat-tempat tertentu di lingkungan, membersihkan parit-parit, atau melaksanakan siskamling. Hal-hal tersebut selain dilakukan oleh kelima kelompok etnik besar yang yang ada di Kecamatan Entikong, kemudian diikuti pula oleh kelompok-kelompok etnik kecil lainnya yang ada meskipun intensitasnya berbedabeda. Keadaan seperti itu menunjukkan tumbuhnya benih konsensus bersama di dalam kehidupan sosial kemasyarakatan.

Jika diamati keberadaan wadah-wadah sosial yang terdapat di Kecamatan Entikong tersebut, tampaknya keikutsertaan setiap individu satuan etnik dalam wadah sosial kemasyarakatan akan lebih memperkokoh iklim kehidupan sosial yang serasi di antara berbagai kelompok etnik. Melalui wadah tersebut terjadi dinamika interaksi yang dilakukan secara teratur, antara lain satu minggu sekali dalam acara pengajian atau wirid yasin setiap malam Jum'at bagi Majelis Taklim atau Bustanul Qur'an khususnya yang beragama Islam, atau setiap hari Minggu bagi Remaja Gereja. Sedangkan wadah sosial yang dilembagakan menampung aspirasi dari berbagai kelompok etnik yang berbeda agama adalah Karang
Taruna. Kalaupun ada yang lain, maka bentuk wadah lain tersebut adalah bersifat kedaerahan atau atas dasar kesamaan suku atau asal daerah seperti Majelis Adat Budaya Dayak (MABD), Majelis Adat Budaya Melayu (MABM), Masyarakat Adat Budaya Tionghoa (MABT), Ikatan Kekerabatan Masyarakat Minang (IKAMAMI), Himpunan Keluarga Batak (HKB), Kerukunan Keluarga Banjar (KKB), dan lain-lainya.

Dalam pelaksanaan aktivitas atau programprogram organisasi tersebut, munculnya benturan atau konflik internal tidak dapat dihindari. Konflik dimaksud antara lain keinginan anggota agar pengurus menerapkan aturan organisasi sebagaimana yang tertuang di dalam Anggaran Dasar dan Anggaran Rumah Tangga seperti pemberlakuan sanksi terhadap anggota yang kurang mau atau tidak mau mengikuti aktivitas organisasi antara lain tidak menghadiri pertemuan rutin sebanyak tiga kali berturut-turut, tidak menghadiri peristiwa kemasyarakatan yang terjadi di kalangan anggota seperti peristiwa musibah atau kematian. Bentukbentuk sanksi tersebut mulai teguran atau peringatan sampai kepada sanksi yang lebih keras yaitu dicoret dari keanggotaan wadah oraganisasi tersebut

Wadah sosial yang khusus mengakomodasikan aktifitas anak-anak muda antara lain adalah wadah Remaja Mesjid untuk remaja yang beragama Islam, Remaja Gereja bagi yang beragama Kristen atau Khatolik. Di Kecamatan Entikong terdapat juga wadah Musyawarah Kerja Gotong Royong (MKGR) yang menampung anak-anak muda dari berbagai kelompok etnik tanpa membedakan agama. Bentuk wadah sosial pemuda seperti ini merupakan wadah yang dibina oleh pihak kelurahan. Melalui wadah tersebut anak-anak muda yang ada di wilayah kelurahan diarahkan untuk ikut serta dalam kegiatan 
sosial yang dilaksanakan. Kegiatan yang paling menonjol dilaksanakan adalah berbagai kegiatan dalam rangka memperingati hari besar seperti HUT Kemerdekaan RI, seperti pertandingan olah raga, berbagai permainan rakyat, dan kegiatan hiburan. Melalui aktifitas olah raga semua individu satuan etnik yang berbeda diharapkan dapat berpartisipasi, baik berpartisipasi dalam hal memberikan sumbangan materi maupun partisipasi langsung sebagai peserta. Momen-momen seperti itu dapat merupakan tolok ukur yang mencerminkan adanya sikap saling memberi dan menerima serta mengukur keberadaan individu suatu kelompok sebagai bagian dari satu kesatuan masayarakat.

Pada umumnya faktor waktu bekerja dianggap sebagai kendala, namun demikian tetap ada mekanisme untuk mengatasinya, antara lain adalah melalui acara pengajian atau yasinan yang dilaksanakan setiap malam Jum'at, dalam melaksanakan ibadah seperti sholat maghrib berjamaah di Mesjid atau Surau, tiap hari Minggu pergi sembahyang ke Gereja bagi yang beragama Kristen, kegiatan gotong royong pada hari Minggu bagi mereka yang tidak ke Gereja.

Meskipun telah berjalannya berbagai aktifitas sosial di Kecamatan Entikong sedemikian rupa yang setiap individu satuan etnik diharapkan dapat berpartisipasi, namun pada kelompok-kelompok etnik tertentu masih kurang menunjukkan partisipasinya secara sunguh-sungguh dalam arti keikutsertaan diri secara langsung.

Berdasarkan hasil observasi dan wawancara yang penulis lakukan di lapangan, ternyata umumnya kelompok etnik yang dimaksud adalah dari kelompok etnik Cina. Keadaan ini ditemui di wilayah pasar sentral dan pusat-pusat perbelanjaan atau pertokoan, dimana sebagian besar kelompok etnik Cina berdomosili. Mereka meskipun ikut berpartisipasi akan tetapi pada umumnya mereka hanya memberikan sejumlah uang kepada orang tertentu untuk menggantikan kehadirannya. Jika kegiatan tersebut adalah gotong royong maka biasanya mereka lebih suka membayar orang atau memberikan sejumlah uang kepada Kepala Lingkungan sebagai ganti ketidakikutsertaan mereka, sedangkan jika kegiatan itu adalah siskamling maka ia akan membayar orang tertentu untuk menggantikannya menjalankan tugas ronda atau siskamling tersebut. Perilaku seperti ini menimbulkan kesan di kalangan warga etnik lain bahwa kelompok etnik Cina itu sombong., tidak mau bergaul, menciptakan jarak, dan sebagainya.

Berdasarkan hasil observasi yang penulis lakukan di lapangan, maka dapat diketahui bahwa ternyata bagi orang Cina sulit untuk memilih waktu tertentu untuk bisa bertemu dengan sesama warga dan termasuk juga dengan sesama etniknya, sebab mereka masing-masing memiliki kesibukannya. Jika seandainya ada kegiatan lingkungan bersama yang diselenggarakan oleh Kepala Lingkungan seperti gotong royong, siskamling, maka biasanya dicari orang lain sebagai pengganti dengan membayar sejumlah uang kepada penggantinya itu oleh karena esok hari akan bekerja. Jika terjadi musibah kematian di lingkungannya kebiasaan mereka berpartisipasi memberikan sumbangan materi, sedangkan untuk menghadiri secara langsung mereka menganggap ada semacam "pantangan”. Adanya pantangan tersebut menyebabkan orang Cina mewakilkan anaknya atau orang lain untuk menghadiri acara prosesi pemakaman tersebut. Dalam hal-hal tertentu seperti seseorang yang ditimpa musibah adalah orang yang sangat dikenal atau rekan bisnis, atau mungkin pegawai atau 
karyawan di pewrusahaannya, maka pantangan tersebut bukam merupakan penghalang untuk menghadirinya.

Kehidupan sosial di kalangan warga etnik yang berbeda agama pun di Kecamatan Entikong tergolong serasi. Hal ini tidak saja terlihat dari kebebasan masing-masing penganut agama melaksanakan ajaran dan keyakinan agamanya, melainkan terwujudnya saling menghormati dan menghargai di antara kelompok-kelompok yang berbeda agama. Hal seperti ini menggambarkan bahwa toleransi dalam kehidupan beragama di antara kelompok-kelompok etnik di Kecamatan Entikong tergolong baik.

Rasa saling menghormati dan menghargai tersebut tampak dalam peristiwa sosial seperti kemalangan dan kegiatan-kegiatan seperti hajatan atau pesta. Di desa-desa seperti Desa Entikong, Desa Semangat, Desa Nekan, Desa Pala Pasong, dan Desa Suruh Tembawang di Kecamatan Entikong berjalan suatu kebiasaan dimana antar warga saling mengunjungi jika terjadi musibah. Mereka juga saling mengunjungi jika satu sama lain saling mengundang pada peristiwa-peristiwa seperti kegiatan pesta. Dalam suatu wilayah desa yang terdiri dari warga etnik yang berbeda agama seperti ditemui di Desa Entikong, Desa Semangat, Desa Nekan, Desa Pala Pasong, dan Desa Suruh Tembawang di Kecamatan Entikong terdapat suatu kebiasaan saling mengundang di antara warga etnik yang berbeda agama dalam kegiatan pesta atau hajatan sebagai wujud adanya saling menghormati. Manakala yang mempunyai hajatan adalah warga etnik yang beragama Kristen atau Khatolik misalnya, maka mereka akan menyediakan makanan yang khusus dimasak menurut ketentuan ajaran agama Islam yang diperuntukkan bagi para undangan yang beragama
Islam. Masakan tersebut sengaja diserahkan kepada seseorang tertentu yang beragama Islam.Kebiasaan seperti itu sebagai wujud rasa menghormati sekaligus menghargai di antara warga yang berbeda agama. Kebiasaan saling mengundang jarang terjadi antara kelompok etnik pribumi dan etnik Cina. Hanya orang-orang tertentu dari kalangan etnik pribumi yang biasa mengundang kelompok etnik Cina, itu pun terbatas pada adanya faktor kenalan atau relasi dagang. Di kalangan etnik Cina jarang menggunakan rumah kediaman sebagai tempat acara pesta

Meskipun terdapat perbedaan dalam kebiasaan saling mengunjungi atau saling mengundang pada kelompok-kelompok etnik tertentu, akan tetapi kehidupan bertetangga di antara kelompok etnik yang berbeda etnik itu masih juga sering terjadi konflik. Adapun bentuk konflik yang sifatnya terbuka hanya berupa perselisihan kecil berupa salah paham antar anak muda. Perselisihan yang terjadi tidak pernah sampai meluas menjadi konflik antar kelompok etnik atau antar agama. Bentuk lain adalah perselisihan antar keluarga karena persoalan yang menyangkut anak-anak kedua belah pihak. Umumnya konflikkonflik terbuka yang intensitasnya relatif kecil tersebut dapat diselesaikan melalui mekanisme musyawarah yang dilakukan oleh tokoh atau pemuka masyarakat. Seperti tokoh masyarakat, tokoh pemuda, aparat lingkungan yaitu Ketua RT atau Kepala Lingkungan, pemuka agama, Adapun tokohtokoh tersebut merupakan sesorang yang dihormati atau disegani oleh kalangan anak muda ole karena perhatiannya yang besar terhadap masalah anak muda.

Kondisi lain yang mencerminkan adanya bentuk konflik adalah yang menyangkut masalah politik dan keamanan masyarakat, yaitu masalah yang pernah terjadi dalam peristiwa pemilihan kepala daerah 
(Bupati) atau Kepala desa, di mana warga masyarakat yang mengusung salah satu calon Bupati atau Kepala desa yang berasal dari salah satu kelompok etnik tertentu selalu saja berusaha untuk meraih dukungan suara terbanyak dengan cara menjelek-jelekan atau menjatuhkan nama baik calon Bupati atau Kepala desa yang berasal dari kelompok etnik lainnya. Konflik ini pada dasarnya merupakan konflik yang sifatnya laten yaitu yang muncul di dalam kehidupan bermasyarakat secara tiba-tiba dan sulit untuk diatasi.

Di samping itu juga, terdapat juga konflik-konflik lainnya, seperti konflik yang menyangkut masalah persaingan dalam memperoleh pekerjaan, masalah tanah, sistem keamanan lingkungan dan kegiatan kerjasama yaitu gotong royong dalam melaksanakan kebersihan lingkungan. Konflik ini juga pada dasarnya merupakan konflik yang sifatnya laten yaitu yang muncul di dalam diri masing-masing individu. Konflik batin seperti ini sulit diperkirakan dan juga sulit untuk diatasi. Adanya konflik ini sangat terkait dengan beberapa aspek seperti kesediaan warga etnik tertentu untuk mau mengalah dalam perselisihan mendapatkan pekerjaan dan masalah tanah, serta tidak adanya kesediaan warga etnik tertentu untuk berpartisipasi dalam kegiata-kegiatan keamanan lingkungan dan gotong royong.

Keengganan individu satuan etnik tertentu untuk mengalah dalam persaingan untuk memperoleh pekerjaan dan tanah dari individu satuan etnik lainnya, serta keengganan individu satuan etnik tertentu untuk berpartisipasi aktif secara langsung secara langsung atau sebaliknya hanya kesediaan untuk memberikan uang sebagai pengganti dirinya atau membayar orang lain untuk menggantikan keikutsertaannya, merupakan kondisi untuk munculnya konflik laten pada diri individu. Secara tidak langsung jika kondisi bahwa terdapat semakin banyak individu satuan etnik yang melakukan hal serupa, maka akan menyebabkan rendahnya intensitas interaksi di antara mereka dan tetap adanya jarak sosial di antara mereka.

Dilihat dari aspek permukiman dalam kerangka pembinaan interaksi sosial, studi yang pernah dilakukan oleh Pelly (1987); dan Andayani (1995), menemukan bahwa di daerah perkotaan di Indonesia terdapat tiga pola permukiman, yaitu pola membaur, setengah membaur, dan terpisah atau segregatif. Pola membaur adalah permukiman di mana penduduknya terdiri dari berbagai etnik, pola setengah membaur adalah permukiman di mana penduduknya terdiri dari berbagai etnik akan tetapi terdapat satu kelompok kecil etnik yang berada di tengah berbagai kelompok etnik tersebut. Pola terpisah atau segregatif adalah permukiman yang mengelompok di mana antara kelompok etnik yang satu dengan etnik yang lain terpisah dan dibatasi oleh batas-batas tertentu. Menurut Budihartono (1993) bahwa kondisi seperti itu umumnya ditemui di pelbagai kota di Indonesia yang memperlihatkan adanya segregasi hunian (residential segregation). Prosesnya terjadi secara sukarela (voluntary) antar pelbagai suku atau bahkan agama.

Menurut hemat penulis jika digunakan tolok ukur aktifitas dimana terbinanya interaksi antar etnik, maka pola permukiman khususnya di Ibukota Kecamatan (Kota Entikong) dapat diklasifikasikan ke dalam dua pola, yaitu: Pertama, pola membaur untuk menunjukkan pada peluang terwujudnya intensitas interaksi yang relatif tinggi, dan Kedua, pola terpisah yang menunjukkan peluang terwujudnya intensitas interaksi yang relatif rendah. 


\section{INTERAKSI ANTAR ETNIK DALAM KEHIDUPAN SOSIAL KEMASYARAKATAN DI KECAMATAN ENTIKONG}

\section{A. Struktur dan Permukiman Kelompok Etnik Di Kecamatan Entikong}

Dalam aspek permukiman tampak bahwa kelompok etnik tertentu mendiami lokasi-lokasi pusat perdagangan dan pusat kota dengan pertokoan dijadikan sebagai rumah kediaman. Umumnya yang mendiami lokasi itu adalah kelompok etnik Cina. Ada pula kelompok permukiman yang berdampingan dengan lokasi permukiman etnik Cina, yaitu kelompok etnik Padang. Keadaan ini terjadi demikian, oleh karena kedua kelompok tersebut mempunyai pilihan (preferensi) yang sama di bidang ekonomi dan perdagangan. Selain itu, bentuk lain polarisasi permukiman penduduk di Kecamatan Entikong adalah terlihat pada permukiman kelompok etnik Dayak dan Melayu. Pada umumnya kelompok etnik Dayak sebagian besar bermukim di kawasan lahan-lahan perkebunan, dan pekerjaan mereka umumnya berkebun.

Pada umumnya kelompok etnik Dayak sebagian besar mendiami daerah pedalaman (daratan), bahkan cenderung bermukim di kawasan hutan dan lahanlahan pertanian yang disesuaikan dengan pola pertanian tradisional mereka (berladang), dan umumnya sebagian besar dari mereka bekerja sebagai petani tradisonal. Karena pemukiman yang demikian, maka mereka pernah disebut oleh kelompok etnik lain sebagai "orang darat". Sedangkan kelompok etnik Melayu sebagian besar bermukim di daerah pesisir sungai dan muara sungai, dan umumnya mereka bekerja sebagai nelayan tradisional, meskipun kecenderungannya sekarang kelima kelompok etnik besar tersebut sudah mulai mengalami perubahan dengan tumbuhnya beberapa permukiman baru sebagai pilihan tempat tinggal mereka.

Berdasarkan data monografi Kecamatan Entikong (2010), tercatat bahwa kelompok etnik Dayak dan Melayu merupakan dua kelompok etnik mayoritas dari segi jumlah dan telah lama bermukim di Kecamatan Entikong, di samping kelompok etnik Cina, dan kelompok etnik lainnya seperti Padang, Jawa, dan Batak. Namun, kelompok-kelompok etnik lainnya yang datang dari luar maupun dari dalam nusantara sendiri, yang secara berturut-turut datang relatif lebih belakangan (baru), turut menambah heterogenitas dan kemulti-etnikan daerah ini. Ini juga menambah keragaman dan kekayaan khasanah sejarah sosial keetnikan di Kecamatan Entikong.

Dua kelompok etnik besar yang bermukim di Kecamatan Entikong (etnik Dayak dan Melayu), merupakan dua kelompok etnik yang telah lama bermukim di daerah ini. Bahkan secara umum dikenal bahwa kelompok etnik Dayak dipandang sebagai penduduk asli di Kecamatan Entikong, sedangkan kelompok etnik Melayu, yang datang ke daerah Kecamatan Entikong lebih belakangan sedikit dari kelompok etnik Dayak, dianggap sebagai penduduk asli kedua. Namun ungkapan "pertama" dan "kedua" tidak menjadi masalah benar bagi anggota kedua kelompok etnik tersebut, karena keduanya hidup secara berdampingan dan saling berinteraksi.

Sebelum tahun 1970, orang-orang Dayak di Kecamatan Entikong berorientasi pada tradisi dan adat Dayak, sehingga mereka menyebut diri mereka sebagai masyarakat adat. Setelah tahun 1970-an, orientasi tersebut telah berubah ke arah agama yang dianut oleh kelompok etnik Dayak baik Islam, Kristen protestan maupun Katholik, terlebih mereka yang menganut kepercayaan nenek moyang. 
Persaingan antara kelompok etnik Dayak baik yang menganut agama/kepercayaan tertentu dengan kelompok etnik lainnya yang menganut agama tertentu lebih mudah timbul dalam orientasi baru semacam ini karena adanya pengidentifikasian kelompok etnik yang mengedepankan agama/kepercayaan yang dianut mereka masingmasing.

B. Sistem Kekerabatan dan Nilai Budaya Kelompok-Kelompok Etnik Di Kecamatan Entikong

1. Sistem Kekerabatan dan Nilai Budaya Kelompok Etnik Dayak

Pada umumnya dalam kehidupan kelompok etnik

Dayak di Kecamatan Entikong terdapat nilainilai budaya yang berlaku di dalam kelompok etniknya. Adapun nilai-nilai budaya tersebut, antara lain :

\section{a. Pangari Bare}

Pangari Bare merupakan bentuk kegiatan tolongmenolong dalam bidang pertanian. Atri bare merupakan kelompok kerja kecil yang terdiri atas $10-15$ orang. Kesesuaian dalam kelompok kerja sangat diperlukan karena kelompok ini harus bekerjasama dalam waktu yang cukup lama. Sebagai contoh warga masyarakat yang tidak mampu bekerja misalnya sakit, cacat, jompo dan lain-lain. Pertolongan itu dapat diberikan secara suka rela demi kemanusiaan, tidak perlu memberikan imbalan.

\section{b. Bappentik}

Bappentik dapat diartikan "berpantang" yaitu tidak boleh mengerjakan sesuatu pekerjaan yang berat atau tidak boleh mengerjakan sesuatu karena ada sesuatu maksud. Dalam Bappentik terkandung pengertian sesuatu yang tabu yang sebaliknya jangan dilanggar. Larangan ini tidak boleh bekerja berat, tidak boleh beprgian jauh karena di desa terjadi peristiwa kematian. Sebagai contoh seluruh warga desa ikut Bappentik apabila di desa ada peristiwa kematian, di mana seluruh warga desa menghentikan kegiatannya, mereka bersiap-siap menuju ke tempat keluarga yang mengalami kematian dengan membawa bantuan sekedarnya.

\section{c. Gawe}

Gawe atau Gawai berarti "pesta besar". Gawe ini banyak berhubungan dengan keyakinan, karena menurut kepercayaan masyarakat Dayak adalah suatu hal yang aib bila di dalam hidupnya seseorang tidak menyelenggarakan gawe. Adapun tujuan dari gawe ini adalah untuk membalas kebaikan arwah orang yang telah meninggal. Gawe ini diikuti oleh seluruh warga yang ada dalam masyarakat di lingkungan satu desa. Pada dasarnya masyarakat suku dayak berprinsip bahwa untuk meningkatkan martabat harus menyelenggarakan satu gawe. Keluarga yang belum pernah menyelenggarakan gawe kedudukannya dalam masyarakat kurang dihormati. Sebagai contoh gawe atau pesta adat dilaksanakan pada waktu hasil panen berlimpah.

2. Sistem Kekerabatan dan Nilai Budaya Kelompok Etnik Malayu

Secara umum suku bangsa Melayu di Kabupaten Sanggau khususnya suku bangsa Melayu di Kecamatan Entikong, mendiami daerah pesisir sungai dan muara sungai. Suku bangsa Melayu ini bercampur dan berbaur dengan suku pendatang yang beragama Islam. Keturunan dari perkawinan campuran antara suku bangsa Melayu dengan suku bangsa lain cenderung mengaku dirinya juga sebagai suku 
Melayu. Pada umumnya sistem kekerabatan sebagai suatu sistem sosial yang ada dalam suku bangsa Melayu di Kecamatan Entikong meliputi

\section{a. Keluarga Inti}

Di dalam kelompok suku bangsa Melayu ini, keluarga inti terdiri dari ayah, ibu dan anakanaknya. Jarang ditemukan keluarga inti yang bersifat poligami dalam arti seorang suami mempunyai istri lebih dari satu orang. Kalau ada suami yang mempunyai istri lebih dari satu orang maka istri-istri lainnya dipisahkan dan membentuk keluarga inti sendiri, dan tidak berada dalam satu rumah tangga dan halaman. Keluarga inti seperti ini adalah keluarga inti yang hidup di kota Nanga Pinoh, karena di kota tempat mereka mencari nafkah.

\section{b. Keluarga Luas}

Di dalam masyarakat suku bangsa Melayu yang hidup di kota Nanga Pinoh jarang ditemukan apa yang disebut dengan keluarga luas, yaitu kelompok kerabat yang terdiri dari lebih satu dari keluarga inti. Tetapi bagi keluarga yang masih bertempat tinggal di tempat asalnya, seperti suku bangsa Melayu yang ada di desa Entikong, desa Semangat, dan desa Nekan, bentuk keluarga luas ini masih didapati. Adapun penyebab utamanya adalah adat yang menentukan bahwa menantu laki-laki harus tinggal di tempat perempuan.

\section{c. Kinred}

Dalam hubungannya dengan kekerabatan suku bangsa Melayu masih ditemukan "Kinred”, yaitu adanya kesatuan kerabat yang melingkari seseorang. Sehubungan dengan aktifitas-aktifitas tertentu, seperti peristiwa perkawinan, kematian dan sebagainya. Biasanya dalam akifitas-aktifitas tertentu itu semua orang yang masih dianggap ada hubungan darah yang dapat ditelusuri diberitahukan dan diundang untuk dapat mengambil bagian. Seandainya ada yang tidak diundang, sedangkan yang bersangkutan masih merasa ada hubungan kerabat dengan yang menyelenggarakan aktifitas, maka yang bersangkutan akan merasa tersinggung. Hal tersebut akan menimbulkan kerenggangan dalam hubungan kekerabatan selanjutnya. Pada umumnya suku bangsa Melayu yang bermukim di Kecamatan Entikong hampir seluruhnya beragama Islam. Agama itu dianut secara turun temurun dengan pemahaman yang cukup tinggi. Sejak kecil anak-anak diajar mengaji untuk mendasari pengetahuan dan keyakinan keagamaannya. Guru mengaji terdapat di manamana di setiap desa. Debat soal agama antara warga yang hidup dalam kelompok terjadi kapan saja. Hal ini menunjukkan bahwa ajaran agama cukup diresapi oleh para pemeluknya. Kelompok-kelompok kecil dalam keagamaan bermunculan seperti kelompok remaja mesjid, kelompok Majelis Taklim, kelompok bersanji, dan lain-lain.

Di dalam kehidupan masyarakat suku bangsa Melayu di Kecamatan Entikong, terdapat nilainilai budaya yang berlaku di kalangan kelompok etniknya. Adapun nilai-nilai budaya tersebut antara lain :

\section{a. Berpepas}

Berpepas adalah selamatan kecil untuk menghindari pengaruh negatif dari sejenis makhluk halus yang ada di sekitar lingkungan 
tempat tinggal. Upacara seperti ini bersifat relegius. Pada dasarnya upacara ini dilakukan dengan pembacaan doa selamat untuk memohon kepada Allah agar dibebaskan dari segala gangguan, kemudian dilanjutkan dengan memercikkan air tepung tawar kepada obyek yang dianggap mendatangkan sial. Berpepas diselenggarakan oleh suatu keluarga atau masyarakat yang disaksikan oleh beberapa tetangga. Sebagai contoh apabila seseorang mendapat berbagai gangguan atau ketidakmujuran yang disebabkan oleh sesuatu di luar kemampuan manusia.

\section{b. Balale (tolong menolong)}

Belale adalah bekerja saling tolong menolong secara bergantian dalam suatu kelompok. Belale merupakan sistem tolong menolong berbentuk pengerahan dalam bidang pertanian. Anggota ini terdiri dari orang-orang yang sepaham. Sebagai contoh pada waktu musim berladang, para petani dalam lingkungan tertentu membentuk suatu kelompok lalean. Seorang anggota lalean merasa wajib untuk membalas bantuan tenaga dari anggota lain yang telah membantunya.

Bantuan tenaga itu merupakan suatu hutang yang harus dibayarnya pada giliran yang telah ditentukan.Pada waktu kena giliran keluarga yang mampu, mereka akan menyediakan makan an, tetapi bagi keluarga yang tidak mampu makanan itu bukan merupakan suatu kewajiban yang harus dipenuhi. Adapun hasil yang dicapai dari dibentuknya sistem lalean ini antara lain bahwa hubungan kekerabatan antara para anggota lalean ini akan terpelihara dengan baik karena satu sama lain saling memerlukan. Hasil lain yang dicapai seperti pekerjaan lebih menarik karena terjadi saling menghibur, saling belajar dan saling bertukar pikiran.

\section{c. Pekatan (Musyawarah)}

Pekatan adalah persetujuan untuk menyelenggarakan saling tolong menolong. Sebagai contuh dalam suatu pesta perkawinan beberapa orang warga masyarakat yang saling dapat bekerjasama mengadakan semacam musyawarah untuk mengadakan suatu pekatan. Dalam musyawarah itu dibicarakan tentang betapa beratnya beban yang harus dipikul oleh seorang keluarga dalam menyelenggarakan pesta. Dalam musyawarah itu diputuskan bahwa semua peserta untuk saling membantu bilamana anggota-anggotanya akan menyelenggarakan pesta perkawinan.

\section{d. Kemit}

Kemit berarti "jaga"dan dapat disamakan dengan ronda malam. Pusat kegiatan kemit ini disebut pos. Pos-pos itu dapat berupa bangunan khusus. Sebagai contoh menjaga kampung merupakan kewajiban seluruh warga masyarakat, karena itu kemit merupakan bentuk kegotongroyongan masyarakat dengan menggerakkan tenaga secara bergantian.

\section{Sistem Kekerabatan dan Nilai Budaya Kelompok Etnik Cina/Tionghoa}

Kelompok suku bangsa Cina/Tionghoa masih termasuk kategori penduduk pendatang, meskipun mereka umumnya sudah lama tinggal di Kecamatan Entikong. Golongan etnik Cina/Tionghoa ini terdiri dari bermacam macam suku bangsa sesuai dengan daerah asalnya di Cina. Menurut daerah asal nenek moyang orang-orang Cina yang pindah ke Kabupaten Sanggau, khususnya Kecamatan Entikong 
terbagi atas suku-suku antara lain Kek, Hoklo, Hokkian, Thin, Chiu, dan lain-lain. Perbedaan suku juga menunjukkan bahasa dan adat istiadat. Antara suku-suku tidak saling berkomunikasi dengan jelas, jika mereka mempergunakan bahasa suku masing-masing.

Dalam masyarakat Cina ada kecenderungan untuk mengembangkan sistem kekerabatan (Siang/Marga) dalam berbagai aspek kehidupan seperti kerjasama dalam perdagangan, perkumpulan kematian, tempat ibadah dan lainlain. Dalam satu siang lebih akrab daripada hubungan sosial dengan lain siang. Namun demikian keturunan Cina ini merupakan pendukung kebudayaan Cina. Kesamaan budaya di antara suku-suku itu dapat dilihat dalam kesamaan jenis upacara tradisional, dalam penyelenggaraan upacara perkawinan dan upacara kematian.

Berdasarkan hasil wawancara dan observasi yang penulis lakukan di lapangan, maka dapat diketahui bahwa sebenarnya nilai-nilai budaya kelompok etnik Cina/Tionghoa sangat berbeda dengan nilai-nilai budaya kelompok etnik lainnya di Kecamatan Nanga Pinoh. Adapun nilai-nilai budaya mereka banyak berasal dari aliran Taoteisme dan Konfucusianisme, yang mana kedua-duanya itu merupakan suatu ajaran keduniawian. Dan untuk lebih jelasnya kedua aliran tersebut, maka dapat dilihat pada penjelasan di bawah ini.

\section{a. Taoteisme}

Taoteisme merupakan aliran tentang jalan yang benar, di mana dasar dan pandangan hidup ini menetapkan kepada hubungan antara manusia dengan alam. Contoh: Ibadah pemujaan yang dilakukannya dipergunakan sebagai sarana untuk memperoleh dan mencapai berkat-berkat duniawi.

\section{b. Konfucusianisme}

Konfucusianisme mengandung faham tentang soal-soal kekeluargaan dan ketatanegaraan yang menyebabkan elompok etnik Cina menjadi masyarakat yang tertutup, eksklusif berdasarkan pada ajaran mengenai penghormatan kepada orang tua, khususnya mengenai kewajiban anak untuk tetap berbakti kepada kedua orang tuanya ini tidak terbatas artinya kewajiban itu ditandai dengan pemujaan terhadap arwah leluhurnya yang dilaksanakan dalam bentuk upacara tradisional Pemujaan ini dilakukan atas dasar pemikiran yang bersumber pada ajaran Kong $\mathrm{Fu} \mathrm{Cu}$. Menurut faham ini, inti kresejahteraan pada masyarakat terletak pada keluarga. Keluarga merupakan inti dari kehidupan tradisional. Sebagai contoh religi masyarakat Cina sangat erat hubungannnya dengan keluarga, di mana upacara-upacara keagamaan dilakukan di rumah-rumah.

\section{Interaksi Antar Kelompok Etnik Dalam Kehidupan Bermasyarakat}

Dinamika kehidupan bermasyarakat pada hakikatnya muncul dalam situasi hubungan atau interaksi yang dilakukan dalam konteks sosial tertentu dan mempunyai fungsi tertentu pula (Pelly, 1973). Interaksi sosial menurut Suparlan (1989: 11) dapat dilihat sebagai interaksi yang terjadi di antara indentitas-identitas sosial yang berbeda yang perwjudannya akan berupa interaksi dari simbolsimbol yang diaktifkan oleh masing-masing pelaku yang terlibat dalam interaksi tersebut. Kualitas hidup bermasyarakat sesungguhnya adalah kualitas yang 
menyangkut hubungan antara manusia pribadi dengan sesama manusia dalam lingkaran sosial atau masyarakat sekelilingnya.

Berdasarkan hasil observasi yang penulis lakukan di Kecamatan Entikong, maka dapat diketahui bahwa interaksi yang terjadi baik dalam kelompok maupun antar kelompok etnik berdampak terhadap perubahan-perubahan pada masyarakat. Hal ini terbukti di dalam masyarakat yang bersifat majemuk yang terdiri dari berbagai suku akan terjadi perubahan-perubahan setahap demi setahap. Suku Dayak maupun suku Melayu di Kecamatan Entikong merupakan masyarakat yang dominan dan menjadi panutan bagi kelompok suku pendatang, dan kelompok suku pendatang tersebut umumnya akan menyesuaikan diri dengan kedua kelompok etnik yang dominan tersebut. Kenyataan ini terbukti dengan mulai terbiasanya masyarakat suku pendatang melakukan kebiasaan sehari-hari orang Melayu, seperti dalam hal masakan, penggunaan alatalat rumah tangga, mandi dan mencuci di sungai yang mungkin menurut kebiasaan daerahnya berbeda. Selain itu adat istiadat sehari-hari yang dibawa oleh setiap suku bangsa, mulai jarang dilakukan. Begitu juga dalam pergaulan mereka sehari-hari sudah jarang menggunakan komunikasi dengan bahasa daerah mereka, tetapi menggunakan bahasa Melayu.

Hubungan yang terjalin antar kelompok etnik besar yang bermukim di Kecamatan Entikong (etnik Dayak, Melayu, dan Cina), akan menciptakan keserasian sosial apabila hubungan itu terjalin dengan harmonis. Mereka tidak lagi bersifat kedaerahan tetapi cenderung lebih mengarah kepada faham nasionalisme. Salah satu kemungkinan terjadinya proses interaksi ini adalah terjaadinya perkawinan antar suku dari masing-masing kelompok etnik. Di sini paling tidak akan terdapat dua adat istiadat yang berusaha dipadukan agar terjalin menjadi satu kesatuan dan dalam hubungan selanjutnya akan melahirkan manusia baru.

Dengan adanya hubungan interaksi yang terus menerus terjadi di dalam kehidupan masyarakat, maka dalam masyarakat akan timbul pandanganpandangan terhadap suku lain baik yang bersifat positif maupun negatif berdasarkan pengalaman yang terjadi sehari-hari. Sesuai dengan pengalaman di lokasi penelitian, keterangan yang jelas dari anggota masyarakat sulit diperoleh karena umumnya mereka khawatir ataupun kurang aman apabila mereka mengemukakan pendapatnya. Namun ada juga anggota masyarakat yang mau mengemukakan pandangan mereka terhadap suku lain.

Pandangan kelompok etnik lain terhadap kelompok etnik Melayu berbeda dengan pandangan terhadap kelompok etnik Dayak. Pada umumnya di Kecamatan Entikong kelompok etnik Melayu mempunyai peranan penting dan bekerja sebagai pegawai negeri, guru, pedagang, buruh, maupun jasa. Pendidikan mereka ada yang lulusan Sarjana (S1), Diploma Tiga (D3), SMA, bahkan ada juga SD. Mayoritas kelompok etnik Melayu ini mempunyai pendidikan yang cukup dan pekerjaan yang mapan. Mereka telah mempunyai wawasan nasional yang cukup, rasa solidaritas yang cukup tinggi karena pada dasarnya kelompok etnik Melayu juga mempunyai nilai-nilai kegotong-royongan yang tinggi.

Sementara itu menurut pandangan kelompok etnik lain terhadap kelompok etnik Dayak, adalah bahwa kelompok etnik Dayak merupakan orangorang yang cinta damai dan pekerjaan pokoknya sebagian besar adalah bertani dan menoreh karet. Mereka umumnya memiliki sifat-sifat jujur, teguh dalam pendirian, sabar dan bersahabat, menghargai orang-orang yang menepati janji, dan cepat 
mempertahankan kehormatan atau harga diri tetapi tidak cepat naik darah.

Berdasarkan berbagai pandangan yang ada pada berbagai kelompok etnik besar di Kecamatan Entikong, maka akan terjadi perubahan-perubahan seiring dengan kemajuan teknologi, industri maupun kemajuan ilmu pengetahuan. Pandangan ini mungkin nantinya tidak dapat berlaku bila diterapkan pada kelompok masyarakat yang mempunyai kehidupan lebih modern, karena pandangan-pandangan ini bersifat tidak tetap. Sedang kelompok masyarakat itu sendiri bersifat dinamis, sehingga sering terjadi perubahan-perubahan dalam kehidupan masyarakat

\section{Kesimpulan}

Berdasarkan analisis data sebagaimana yang telah dipaparkan sebagaimana tersebut di atas, maka penulis menarik beberapa kesimpulan, yakni sebagai berikut :

1. Dinamika hubungan sosial antaretnik terwujud dalam bentuk hubungan sosial yaitu hubungan sebagai anggota keluarga atau kerabat, sebagai sahabat, dan sebagai teman atau kenalan. Di antara jenis hubungan tersebut tampak masih kuat kesetiaan primordial di kalangan kelompokkelompok etnik. Hal itu ditandai oleh kecenderungan untuk memilih individu dari kelompok etnik sendiri untuk dijadikan sebagai kerabat. Jenis hubungan sebagai sahabat dan sebagai teman atau kenalan terdapat variasi pilihan, yaitu selain memilih individu dari kelompok etnik sendiri, juga memilih individu dari kelompok etnik lain.

2. Munculnya unsur prasangka sosial dan stereotipe antaretnik bukan merupakan factor penghalang interaksi social dalam rangka memperkokoh iklim keserasian social. Jarak social antaretnik merupakan factor yang dapat melemahkan kokohnya iklim keserasian social oleh karena tingkat intimasi individu antar etnik relative rendah. Munculnya prasangka social dan stereotipe negatif di antara individu-individu satuan kelompok etnik disebabkan oleh rendahnya tingkat keikutsertaan individu satuan kelompok-kelompok etnik dalam berbagai kegiatan social kemasyarakatan, seperti dalam kegiatan gotong royong lingkungan, kegiatan siskamling, kegiatan olah raga, dan saling mengunjungi wartga yang ditimpa musibah. Keikutsertaan individu dalam berbagai kegiatan social kemasyarakatan dapat mengeliminir prasangka dan stereotype negative serta mengurangi jarak social di antara individu satuan kelompok-kelompok etnik.

3. Perbedaan tingkat pendidikan, agama, dan durasi menetap kecil pengaruhnya terhadap terbinanya iklim interaksi social dalam memperkokoh iklim keerasian social. Dalam hal ini, factor jumlah waktu bekerja individu satuan etnik yang menyebabkan rendahnya frekuensi interaksi social.

4. Penggunaan bahasa daerah di kalangan individu satuan kelompok-kelompok etnik yang berbeda sebagai media komunikasi merupakan iklim yang kurang kondusif untuk menghilangkan prasangka dan stereotype negative. Hal tersebut disebabkan oleh ketiadaan pemahaman bersama terhadap makna-makna pembicaraan yang menggunakan bahasa daerah. Penggunaan bahasa daerah di kalangan kelompok etnik khususnya di tempat-tempat umum secara tidak langsung mempertegas "batas social", memperlebar jarak social antaretnikdan menunjukkan suatu kelompok etnik sebagai 
kelompok tertutup. Kesadaran untuk menggunakan bahasa Indonesia dalam situasi social atau tempat-tempat umum merupakan perilaku yang dapat mengurangi prasangka dan stereotype negative serta mempertebal tingkat intimasi social di antara individu satuan kelompok etnik.

5. Dalam kehidupan social, peluang untuk kokohnya iklim keserasian social adalah sama dengan peluang untuk melemah atau munculnya konflik. Salah satu upaya untuk lebih memperkokoh iklim keserasian social di wilayah perbatasan adalah melalui institusi social masyarakat sebagai sarana yang dapat mengembangkan berbagai kegiatan social. Fungsi institusi social ini sebagai sarana bagi individu dari berbagai kelompok etnik untuk berinteraksi. Berbagai wadah-wadah social tersebut, antara lain yang didasarkan atas kesamaan agama seperti Ikatan Remaja Mesjid, Ikatan Remaja Gereja, Persatuan Dayak Islam, maupun berdasarkan kesamaan etnik seperti Perkumpulan Warga Dayak, Perkumpulan Warga Cina, dan Perkumpulan Warga Melayu.

6. Dilihat dari peluang untuk terbinanya interaksi antaretnik diwilayah perbatasan, maka ada dua bentuk pola permukiman kelompok etnik di kota Entikong yaitu: (1) Pola membaur, wilayah permukiman yang di dalamnya terdiri dari berbagai kelompok etnik, di dalamnya terjadi kontak social antaretnik yang lebih intensif yang dapat mendorong terwujudnya keserasian social. Termasuk dalam pola ini adalah komplek perumahan atau kawasan perumahan yang sengaja dibangun oleh pengembang; (2) Pola terpisah, wilayah permukiman yang di dalamnya terdiri dari satu kelompok etnik sejenis. Pola permukiman seperti ini umumnya dihuni oleh kelompok etnik Cina. Terjadinya perubahan pola permukiman penduduk secara tidak langsung disebabkan oleh perluasan kawasan kecamatan serta pertambahan penduduk.

\section{Saran-Saran}

Untuk lebih memantapkan iklim keserasian sosial yang sudah terbina, perlu diciptakan kondisi untuk semakin intensifnya interaksi di antara kelompok etnik yang setiap individu satuan etnik dapat saling menerima keberadaan orang lain melalui sosialisasi konsep konsensus, kebersamaan, keterbukaan, kerukunan, dan solidaritas dalam lingkungan masyarakat. Selain itu perlu dibina kesadaran dan penerimaan tiap-tiap individu mengenai keberagaman serta perbedaan budaya masing-masing kelompok etnik. Iklim keserasian sosial yang sudah terbina tampaknya tetap mengandung potensi konflik, untuk itu iklim keserasian sosial perlu dimantapkan. Adapun strategi yang dapat ditempuh adalah melalui strategi struktural dan strategi kultural.

Strategi Struktural : merupakan strategi yang lebih menekankan pada upaya pemantapan kesderasian sosial yang dilakukan melalui berbagai kebijakan pemerintah antara lain:

a) Pemberian pelayanan secara seimbang, proporsional, transparan, dan adil dalam setiap urusan yang berkenaan dengan kepentingan masyarakat seperti urusanurusan di kantor-kantor pemerintah. Termasuk anjuran secara konsisten mengenai keikutsertaan setiap warga dalam berbagai kegiatan sosial di lingkungan permukiman. 
b) Perlu dirumuskan suatu bentuk wadah yang melintasi perbedaan etnik dan juga agama yang dapat mengakomodasikan individu dari kelompok-kelompok etnik yang berbeda latar belakang agama dalam aktifitas sosial kemasyarakatan. Bentuk wadah tersebut dapat berupa "Forum Sarasehan" yang dapat berfungsi sebagai forum komunikasi warga serta mengembangkan jaringan sosial dalam melahirkan kesepakatan, merencanakan kegiatan bersama seperti di bidang ekonomi, mewujudkan kebersamaan terhadap setiap masalah yang dihadapi di dalam lingkungan permukiman. Upaya ini sebagai cara untuk menguatkan solidaritas horisontal antara sesama warga.

c) Agar di antara individu-individu satuan etnik yang berbeda dapat lebih intensif berkomunikasi, maka perlu kesadaran individu satuan etnik untuk menggunakan Bahasa Indonesia. Selain usaha-usaha yang sudah dilakukan berupa himbuan melalui poster seperti "Berbicaralah Dengan Menggunakan Bahasa Indonesia Yang Baik Dan Benar", atau "Gunakanlah Bahasa Indonesia Di tempat-Tempat Umum", maka usaha-usaha seperti itu harus ditingkatkan antara lain penyuluhan dan pemasangan poster serupa ke lembagalembaga seperti sekolah terutama sekolah yang didominasi oleh kelompok etnik tertentu, pusat-pusat pelayanan umum seperti pusat perbelanjaan, perkantoran, rumah sakit. Khusus untuk lembaga pendidikan tidak hanya terbatas pada anjuran, tetapi harus diikuti dengan pengawasan dari instansi terkait.

Strategi Kultural : merupakan upaya yang dilakukan untuk mempengaruhi perilaku sosial dan penyadaran anggota masyarakat yang sifatnya individual. Upaya yang termasuk dalam strategi ini antara lain pesan-pesan komunikasi melalui berbagai pertemuan, media massa seperti koran, majalah atau media elektronik seperti acara TV lokal, acara-acara radio lokal. Kemudian selebaran atau edaran, pesan melalui dakwah oleh tokoh-tokoh agama dan tokoh masyarakat, imam, pendeta, pemimpin organisasi yang isinya adalah menekankan perlunya kesetiakawanan sosial sebagai wujud dari kehidupan yang serasi. Pesan komunikasi tersebut pada intinya adalah menyadarkan kepedulian tiap individu untuk menumbuhkan rasa kesetiakawanan sebagai satu kesatuan masyarakat yang demikian beragam dalam rangka mewujudkan dan mempertahankan iklim hubungan sosial yang serasi dan kokoh.

Untuk menambah gambaran tentang keserasian sosial masyarakat di kecamatan secara holistik, perlu dilakukan penelitian lanjutan dengan hal-hal yang dapat dijadikan tumpuan perhatian antara lain bentuk kelembagaan, mekanisme serta kegiatan-kegiatan "Forum Komunikasi Warga" yang lebih memiliki asas manfaat. Ada kecenderungan besarnya peran serta individu dalam suatu wadah sosial dipengaruhi oleh seberapa besar manfaat yang bisa diperoleh dari keikutsertaan mereka. Perlu pula dilakukan studi komparatif tentang bentuk-bentuk keserasian sosial dalam masyarakat di kecamatan-kecamatan lain di Indonesia yang mempunyai keberagaman masyarakat yang sama dengan Kecamatan Entikong 
terutama keberagaman etnik antara lain model-model kerja sama ekonomi antar etnik, bentuk-bentuk kelembagaan ekonomi yang dapat mengakomodasikan aktifitas ekonomi di antara individu dari kelompok-kelompok etnik. Hasil studi seperti itu akan lebih melengkapi kajian mengenai karakteristik dan model-model kehidupan masyarakat kecamatan yang plural dalam rangka mewujudkan keserasian sosial di seluruh Indonesia

\section{DAFTAR PUSTAKA}

Bahari, Yohanes. 2005. Model Resolusi Konflik Berbasis Pranata Adat Pada Masyarakat Adat Kanayatn di Kalimantan Barat. Laporan Penelitian Fundamental, Dikti.

Barth, Fredrick. 1969. Kelompok Etnik dan Batasannya. Terjemahan Nining L. Soesilo. Jakarta: UI Press.

Bogdan, Robert C \& Taylor, Steven J. 1990. Introduction To Qualitative Research Methods. Alih Bahasa Arief Furchan. Surabaya: Usaha Nasional.

Bruner, Edward M. 1974. " The Expression of Ethnicity in Indonesia". Dalam Abner Cohen (ed) : Urban Ethnicity. London: Tavistock Publications.

Cohen, Abner. 1974. "Introduction". dalam Abner Cohen (ed). Urban Ethnicity. London: Tavistock Publications.

Cohen, Jacob,Cohen, Patricia. 1983. Applied Multiple Regression/Correlation for yhe Behavioral Sciences, London: Lawrence Erlbaum Associates, Publishers.

Coser, Lewis A. 1956. The Functions of Social Conflict. New York: The Free Press.

Eidheim, Harald. 1969. "Ciri Etnik Sebagai Cacat Sosial" , dalam Frederick Barth (ed). : Kelompok Etnik dan Batasannya. Penerjemah: Nining L. Soesilo, Jakarta: UI Press.

Furnivall, J.S. 1980. "Plural Society", dalam HansDieter Evers (ed). Sociology of South-East Asia: Readingin Social Change and Development. Kuala Lumpur: Oxford University Press.

Gelfand, Donald E. 1973. "Influx-Exodus: An Explanatory Study of Racial Integration", in Donald E. Gelfand and Russell D. Lee (ed). : Ethnic Conflicts and Power: A Cross-
National Perspective. New York: John Wiley \& Sons, Inc.

Giring. 2004. Madura di Mata Dayak: dari Konflik Ke Rekonsiliasi. Yogyakarta: Gajah Mada University Press.

Grillo, R.D. 1974. "Ethnic Identity and Social Stratification on a Kampala Housing Estate", dalam Abner Cohen (ed) : Urban Ethnicity. London: Tavistock Publications.

Horton, Paul B. 1965. Sociology and The Health Sciences. New York: Mc Graw-Hill Book Company.

Izikowitz, Karl G. 1969. "Lingkungan Hidup di Laos", dalam Frederick Barth (ed) : Kelompok Etnik dan Batasannya. Penerjemah: Nining L. Soesilo, Jakarta: UI Press.

Koentjaraningrat. 1991. Metode-Metode Penelitian Masyarakat. Jakarta: Gramedia.

Martodirdjo, Haryo S. 1991. Orang Tugutil di Halmahera dan Dinamika Sosial Masyarakat Penghuni Hutan. Bandung: Disertasi Program Pascasarjana Unpad.

Miles, Matthew B. \& Huberman, A. Michael. 1992. Analisis Data Kualitatif. Jakarta: UI Press.

Mitchell, J.C. 1974. "Perception of Ethnicity and Ethnic Behavior: An Empirical Exploration", dalam Abner Cohen (ed) : Urban Etthnicity. London: Tavistock Publications.

Nawi, Abdullah. 1986. "Peranan Kebudayaan Kebangsaan Dalam Integrasi Rakyat", dalam Cheu Hock Tong (Penyunting): Beberapa Asas Integrasi Nasional Pro dan Kontranya. Kuala Lumpur : Penerbit Karya Kreatif.

Parsons Talcott. 1951. The Social System. New York: The Free Press.

Peh, Ting Chew. 1986. "Sains Sosial dan Integrasi Nasional", dalam Cheu Hock Tong (Penyunting): Beberapa Asas Integrasi Nasional Pro dan Kontranya. Kuala Lumpur: Penerbit Karya Kreatif.

Pelly, Usman. 1987. "Kulitas Bermasyarakat". Ringkasan Hasil Penelitian. Jakarta: kantor Menteri Negara KLH.

1993. "Pedoman Pengelolaan Keserasian Sosial". Laporan Penelitian. Kerjasama Kantor Menyeri KLH dengan Pusdip-KLH IKIP Medan.

Poloma, Margaret M. 1987. Sosiologi Kontemporer (Terjemahan), Jakarta: Penerbit CV. Rajawali.

Purwana, Hendarta Suta. 2003. Konflik Antarkomunitas Etnis di Sambas 1999. Suatu Tinjauan Sosial Budaya. Pontianak: Romeo Grafika. 
Royce, Anya Peterson. 1982. Ethnic Identity. Bloomington: Indiana University.

Soehardiman. 1985. "Pembauran Bangsa Sebagai Usaha Pemanunggalan Dalam Rangka Mewujudkan Persatuan dan Kesatuan Nasional", dalam Walkodri dan Djudjuk Juyoto. Pembauran Bangsa : Suatu KonsepKonsep Pemikran. Yogyakarta: CV. Nur Cahaya.

Soekanto, Soerjono. 2002. Teori Sosiologi Tentang Perubahan Sosial. Jakarta: Ghalia Indonesia.
Soemardjan, Selo. 1988. "Pendahuluan", dalam Selo Soemardjan (ed). Stereotipe Etnik, Asimilasi. Integrasi Sosial, Jakarta: Pustaka Grafika Kita.

Suparlan, Parsudi. 1989. "Pendahuluan", dalam Parsudi Suparlan (ed), Interaksi Antaretnik di Beberapa Provinsi di Indonesia, Jakarta: Depdikbud.

Veeger, K.J. 1985. Realitas Sosial. Jakarta: Penerbit PT Gramedia. 